\title{
Özel Eğitim Öğretmeni Adaylarının İş Birliğine İlişkin Metaforik Alg1lar1
}

\author{
Eylem DAYI ${ }^{1}$ ve Zahide TÖRET ${ }^{2}$
}

$\ddot{O ̈}_{z}$

Özel eğitim, merkeze aldığı öğrencilerin bireysel farklılıkları nedeni ile özel eğitim öğretmenlerinin farklı alanlardan gelen uzmanlarla sıkça iş birliği kurmasını gerektiren bir disiplin alanıdır. Bu çalışmada özel eğitim öğretmeni adaylarının iş birliğine yönelik metaforik algıları ve oluşturdukları metaforların gerekçeleri incelenmiştir. Araştırmada 93 özel eğitim öğretmeni adayının iş birliğine yönelik oluşturduğu metaforlar ve metaforlarının gerekçeleri incelenmiştir. Verilerin toplanması için araştırmacılar tarafından oluşturulan Metaforik Algı Anketi kullanılmıştır. Ankette "Özel eğitimde iş birliği...........gibidir, Çünkü, .....”" şeklinde yarı yapılandırılmış bir soru yer almıştır. Araştırma sonunda özel eğitim öğretmen adaylarının iş birliğinin yapısı, iş birliğine yönelik tehditler, iş birliğinin gereklilikleri, önemi, amacı olmak üzere toplam beş farklı temada 56 farklı metafor ürettikleri sonucuna ulaşılmıştır. Elde edilen sonuçlar alanyazında var olan çalışma sonuçları ile karşılaştırılarak yorumlanmıştır.

Anahtar Kelimeler: İş birliği, Özel Eğitim, Özel Eğitim Öğretmeni, Öğretmen Aday1, Metafor, Alg1

\section{Metaphoric Perceptions of Preservice Special Education Teachers Regarding Collaboration}

\section{Abstract}

Special education is a field that requires special education teachers to collaborate frequently with specialists from different fields due to the individual differences of the students. This study examined the metaphorical perceptions of preservice special education teachers about collaboration, as well as the reasons for the metaphors they created. The study examined metaphors created by 93 special education teachers prior to collaborating, and their reasons. Metaphoric Perception Survey, created by researchers, was used for data collection. The questionnaire has a semistructured question such as "Collaboration in special education ...........". Because ..... ". At the end of the study, the preservice special education teachers' structure in five different themes, the structure of the collaboration, the threats to collaboration, the requirements of the collaboration, the importance of the collaboration and the purpose of the collaboration.

Key Words: Collaboration, Special education, Special education teacher, Preservice teacher, Metaphor, Perception

\section{Atıf İçin / Please Cite As:}

Dayı, E. ve Töret, Z. (2021). Özel eğitim öğretmeni adaylarının iş birliğine ilişkin metaforik algıları. Manas Sosyal Araștırmalar Dergisi, 10(2), 863-877.

Geliş Tarihi / Received Date: 27.05.2020

Kabul Tarihi / Accepted Date: 19.03.2021

\footnotetext{
${ }^{1}$ Doç. Dr. - Gazi Üniversitesi Gazi Eğitim Fakültesi, eylemd@gazi.edu.tr

iD ORCID: 0000-0003-1020-5846

2 Araş. Gör. - Gazi Üniversitesi Gazi Eğitim Fakültesi, zahidetoret@gazi.edu.tr

(iD ORCID: 0000-0003-2102-9876
} 


\section{Giriş}

"İşs birliğı" kavramı 21. yüzyılda sanayileşmenin gelişmesiyle hemen hemen tüm alan profesyonellerinin kazanması gereken bir beceri olmaya başlamıştır. İş birliği içinde çalışma süreci birden fazla alan uzmanının fikir ve mesai ortaklığını içermektedir. Sonuç olarak daha kapsamlı çözümlere ulaşmak, birlikte karar almak ve olası hata oranlarını düşürmek söz konusu olabilmektedir. Bu nedenle işbirlikçi çalışma örneklerinin insan kaynakları, sağılı, eğitim gibi birebir insan ile çalışan hizmet sektörlerinde giderek artan bir rağbetle kullanıldığ1 söylenebilir. Özellikle özel eğitimde eğitimin merkezinde yer alan öğrencinin bireysel farklılıklarına cevap verecek ve öğrencinin ilerlemesini sağlayacak programların hazırlanması, uygulanması ve değerlendirilmesi için farklı meslek uzmanlarının görüşlerine başvurulması gerekliliği her boyutuyla iş birliği içinde çalışma becerilerini gerektirmektedir.

Alanyazın incelendiğinde özel eğitimde iş birliğini konu alan pek çok çalışmaya rastlanmaktadır. Örneğin özel eğitimde iş birliği kalitesinin öğretmen ve yardımc1 personelin becerilerinden, okulun ve idarecilerin yapısından etkilendiğini belirten çalışmaların yanı sıra (Biggs, Gilson ve Carter, 2016, s. 256), iş birliğine katılan öğretmenlerin süreci sürdürebilmeleri için ortak bir amaç, ortak felsefe ve dil paylaşmalarının gerekliliğini gösteren çalışmalara rastlamak da mümkündür (Carter, Prater, Jackson ve Marchant, 2009, s. 60). Bununla birlikte Brownell, Adams, Sindelar ve Waldron (2006) iş birliğine ilişkin hizmet içi eğitim almış öğretmenlerin bir grubunun problem çözmede işbirlikçi yaklaşımlardan etkin bir biçimde yararlanırken bir grup öğretmenin ise daha sınırlı düzeyde bu becerilerden yararlandığını belirlemişlerdir. Temel farklılığın kaynaklarını araştırdıklarında ise müfredat düzenleme, öğrenci ile iletişim, pedagoji ve uyarlama konusunda daha yetkin olan öğretmenlerin problem çözmede işbirlikçi yaklaşımlara daha fazla yöneldikleri sonucuna ulaşmışlardır. Bu çalışma ile dolaylı olarak tutarlı sonuçlar içeren başka bir çalışmada ise mezun oldukları lisans programında kapsayıcı eğitim ve iş birliği ile ilgili ders alan öğretmenlerin mesleğe atıldıklarında işbirlikçi çalışmalar konusunda kendilerini daha yetkin hissettikleri sonucuna ulaşılmıştır (Zagona, Kurth ve Mac Farland, 2017, s. 163). Lynch, Madden ve Knight (2014) yapmış oldukları bir çalışmada öğretmenlere iş birliğine dayalı bir öğretim içeriği sağlandığında ögretmenlerin mesleki becerilerine ilişkin kapasitelerini daha etkin ve verimli bir biçimde kullanabildikleri sonucuna ulaşmıslardır.

Hali hazırda çalısmakta olan öğretmenlerin sahip oldukları beceri ve bilgilerin iş birliğinin kalitesini artırdığını gösteren çalışmaların yanı sıra hizmet öncesi dönemlerde alınan eğitimlerin de öğretmenlerin iş birliğine ilişkin becerilerini desteklediği bilinmektedir. Örneğin; Vuran, Bozkuş-Genç ve Sani-Bozkurt (2017) yapmış oldukları bir çalışmada "zihin engelliler öğretmenliği programına" devam eden öğretmen adaylarına iş birliği ile bireyselleştirilmiş eğitim programları (BEP) geliştirmeye yönelik bir eğitim sağlamışlardır. Çalışma sonunda öğretmen adaylarının BEP hazırlamanın bir gerekliliği olan iş birliği becerilerinin arttığı, iş birliği ile BEP hazırlama sürecinde öğretmen adaylarının birbirleriyle etkili iletişim kurdukları ve gruba aidiyetlerinin arttığını bildirdikleri sonucuna ulaşılmıştır. Gürgür ve Uzuner ise (2010) kaynaştırma ortamlarında iş birliğine dayalı uygulamaları sınıf öğretmeni ve uygulamacı görüşlerine dayalı olarak incelemişlerdir. Araştırma sonunda araştırmacılar bir programın başarılı olmasında paydaşların algılarının ve sürece aynı anlamı yüklemelerinin, tutum ve niyetlerinin benzer olmasının önemli olduğunu vurgulamıştır. Öğretmenlerin genel olarak iş birliği konusunda eğitim almaları gerektiğini ifade eden araştırmacılar, öğretmenlerin niyet, bilgi, beceri, eylem ve sonuca ulaşma döngüsünü içselleştirmeleri gerektiğini ifade etmişlerdir (Gürgür ve Uzuner, 2010, s. 15). Yener (2019) yüksek lisans tez çalışmasında kaynaştırma ortamlarında çalışan öğretmen ve uzmanların BEP sürecinde yaptıkları iş birliklerine ilişkin görüşlerini, aile ve uzman görüşmelerine dayalı olarak incelemiştir. Sonuç olarak kaynaştırma ortamlarında çalışan uzmanların BEP hazırlama ve uygulama sürecinde iş birliği yapmadıklarını raporlamıştır. Özel eğitim okul ve sınıflarında çalışan özel eğitim ve branş öğretmenleri arasındaki iş birliği çalışmalarının incelendiği başka bir çalışmada ise özel eğitim öğretmenleri ve branş öğretmenleri arasında özellikle öğrenci için eğitim ve eğitsel faaliyetlerin içeriklerinin belirlenmesinde iş birliği yapıldı̆̆1 sonucuna ulaşılmakla birlikte öğretmenlerin bu süreçte iş birliğinin esaslarına uygun olarak paylaşımlarda bulunmadığı sonucuna ulaşılmıştır (Elçi, 2019). Elde edilen bu sonuçlar bir araya getirildiğinde kaynaştırma ve bütünleştirme ortamlarında çalışacak öğretmen adaylarının iş birliğine ilişkin becerilerinin geliştirilmesi için öğretmen adaylarının aldığı eğitimlerin önem taşıdığı anlaşılmaktadır. Hamilton- Jones ve Vail (2013) ise hizmet öncesi özel eğitim öğretmenleri ile yaptıkları bir çalışmada, işbirlikçi becerilere yönelik bir eğitim sonucunda öğretmen adaylarının iş birliği yapıldığında, elde edilecek çıtıların daha çeşitli ve farklı olabileceği yönünde fikir değiştirdikleri sonucuna ulaşmışlardır. Diğer taraftan işbirlikçi çalışmaların öğrenci çıktılarını da olumlu yönde etkilediği bilinmektedir. Yapılan çalısmalarda başarılı olarak 
sayılabilecek okulların temel özelliklerinin işbirlikçi yaklaşımı benimsemek olduğu rapor edilmektedir (Caron ve McLaughlin, 2002, s. 285). Bunun yanı sıra uzmanların kendi arasında ve ailelerle iş birliği yaptığ1 okullarda öğrenci başarısının arttığı, sosyal uyum becerilerinin geliştiği ve problem davranışların azaldığ1 rapor edilmektedir (Hunt, Soto, Maier ve Doring, 2003, s. 315).

Özetlemek gerekirse özel eğitimde iş birliği öğretmenlerin ve öğretmen adaylarının belli eğitim ve tecrübeler sonunda, kendi beceri ve yeteneklerinin de yardımı ile geliştirdikleri bir kavramdır (Biggs vd., 2016, s. 256; Brownell vd., 2006, s. 169). Ayrıca öğretmenlerin ve diğer alan uzmanlarının benzer bakış açısına sahip olmaları (Gürgür ve Uzuner, 2010, s. 15) ve öğretmenlerin fikirlerini rahatça tartışabilmeleri ögretmenlerin iş birliğine ilişkin tutumlarını olumlu olarak etkilemektedir (Lynch vd., 2014, s. 1). Bununla birlikte yapılan çalışmalar öğretmen adaylarının uygun eğitimleri aldıklarında iş birliğine ilişkin bilgi ve becerilerinin arttığını işaret etmektedir (Biggs vd., 2016, s. 256; Brownell vd., 2006, s. 169; Hamilton vd., 2013, s.76; Vuran vd., 2017, s. 165; Zagona vd., 2017, s. 163).

Bu çalışmada özel eğitim öğretmeni adaylarının iş birliğine yönelik algıları incelenmiştir. Araştırmaya katılan özel eğitim öğretmeni adaylarının doğrudan özel eğitimde iş birliğine yönelik ders almamış olması ve son sınıfta olmaları nedeni ile kavrama ilişkin temel algılarının ne olduğu merak konusudur. İş birliği kavramı pek çok özellik ve kendine has esasları olan, kolayca açlklanamayacak bir kavram olarak (Cook ve Friend, 1991; Cook ve Friend, 2010, s. 1; Friend ve Cook, 1992) tanımlanmaktadır. Bu nedenle özel eğitim öğretmeni adaylarının iş birliğine ilişkin algılarını metaforlar yardımı ile açıklamaları algılarının anlaşılması bakımından kolaylaştırıcı olabilir. Nitekim alanyazında bilinmeyen kavramlara ilisskin algıların metaforlarla açıklanabileceği, bunun az bilinen ya da hiç bilinmeyen bir kavrama ilişkin algıların açıklanmasında uygun bir yol olabileceği vurgulanmaktadır (Cerit, 2008, s. 693; Ekici, 2016, s. 755; Martinez, Saudela ve Huber, 2001, s. 965).

Metaforlar, bireylerin bazı benzetme unsurlarını kullanarak, açıklayamadıkları bazı kavramları açıklamalarını sağlar. Bu nedenle kavrama ilişskin metaforik algılar kavramın zihindeki durumunun ortaya çıkması açısından önem taşımaktadır (Tamimi, 2005; Yazar, Özekinci ve Lala, 2017, s. 245). "İş birliği” ise hem yasa ve yönetmeliklerle hem de eğitim sunduğu grubun bireysel farklılıkları ve ihtiyaç duyduğu farklı eğitsel müdahalelerin karşılanabilmesi için özel eğitim öğretmeni adaylarının zorunlu olarak kullanacağı ve içinde bulunacağı bir süreç olmaktadır. Çalışmaya katılan öğretmen adaylarının son sınıfta olmaları ve kısa süre içinde sahada yer alacakları düşünüldüğünde ise, iş birliğine yönelik algılarının metaforlar yoluyla belirlenmesi sonunda elde edilecek sonuçların, bu konuda hizmet öncesi ve hizmet içi eğitimlere yönelik içeriklerin geliştirilmesine öneri sunulabilmesi bakımından yararlı olacağı düşünülmektedir. Ayrıca araştırmadan elde edilen sonuçların alanyazına nitelikli veriler sağlayacağı varsayllmaktadır.

\section{Araştırmanın Amacı}

$\mathrm{Bu}$ araştırmanın amacı, özel eğitim öğretmeni adaylarının "iş birliğ̣”" kavramılla ilgili geliştirdikleri metaforları analiz etmektir. Bu kapsamda aşağıdaki sorulara cevap aranmıştır:

1. Özel eğitim öğretmeni adaylarının "iş birliğı" kavramıla ilgili oluşturdukları metaforlar nelerdir?

2. Belirtilen metaforlar ortak özellik bakımından hangi temalar altında toplanmaktadır?

\section{Yöntem}

Bu araştırmanın amacı, Özel eğitim öğretmeni adaylarının "iş birliğı” kavramılla ilgili geliştirdikleri metaforları analiz etmektir. Araştırmada özel eğitim öğretmeni adaylarının bireysel alg1 ve tecrübelerinden yola çıkılarak "iş birliğı" kavramına ilişkin metaforik algıları incelenmiştir. Bu nedenle araştırmanın deseni nitel araştırma modellerinden olgubilim (fenomenoloji) desenidir. Olgubilim deseni, yaygın uygulamaları ortaya çıkarmak ve katılımcılar tarafından oluşturulan anlamları/olguları tanımlamak ve açıklamak amacıyla kullanılmaktadır. Olgubilim deseninin temelini bireysel tecrübeler oluşturmaktadır. Olgubilim tanımlayıcı bir araştırma desenidir. Bu bağlamda genelleme yapmak değil, olguları tanımlamak ve kişisel deneyimlere dayalı sonuçları belirlemek önemlidir (Akturan ve Esen, 2008, s. 83-98).

\section{Evren- Örneklem}

Çalışmanın verileri Gazi Üniversitesi Gazi Eğitim Fakültesi Özel Eğitim Öğretmenliği Lisans Programı dördüncü sınıfa devam eden özel eğitim öğretmen adaylarından toplanmıştır. Araştırmaya katılan katılımcıların araştırmaya katılmak için gönüllü olması, kayıtlı olduklanı lisans programına devam ediyor olması ve öğretmenlik uygulaması dersini alıyor olması şartları aranmıştır. Araştırma kapsamında toplam 
107 katılımcıya ulaşılmıştır. Ancak 14 katılımcının anketi uygun doldurmadığı anlaşılmıştır. Analiz edilmeye uygun veri sağlayan 93 katılımcının 45’i görme engelliler öğretmenliği programına ve 48’i zihin engelliler öğretmenliği programına devam etmektedir.

\section{Veri Toplama Araçları}

Metaforik Algı Anketi. Verileri toplamak amacıyla birinci ve ikinci araştırmacı birlikte alanyazında yapılan çalışmaları tarayarak (Büyükalan ve Yaylacı, 2018, s. 679; Dayı, Açıkgöz ve Elçi, 2020, s. 95; Ekici, 2016, s. 755; Yazar vd., 2017, s. 245) "Metaforik Alg1 Anketi" oluşturmuşlardır. Anket "katıllımcı bilgilerine ilişkin sorular" ve "iş birliğine yönelik metaforik algilara yönelik sorular" olmak üzere iki kısımdan oluşmuştur. Katıılımcı bilgilerine yönelik kısımda katılımcıların cinsiyet, sınıf, yaş bilgileri yer almışır. Metaforik algilara ilişkin olan bölümde katılımcılara "Türkçe'de metafor mecaz olarak bir şeyi başka bir şeyle açıklamak, daha anlaşılır olanla açılamaya çalışmaktır. Bir nevi istenilen kavram ile ilgili düşünceleri somutlamaktır. Aşağıda bulunan ankette iş birliği denince aklınıza gelen kavramı ve iş birliğini neden bu kavrama benzettiğinizi gerekçelendiren bir sebep cümlesini tamamlamanız istenmektedir. Her iki cümleyi de eksiksiz, mantıklı ve okunaklı bir şekilde tamamlamanız gerekmektedir. İş birliği kavramına ilişkin bu görevi daha iyi anlamanız için aşağıda "Aile" kavramına ilişkin örnekler yer almaktadır." şeklinde bir açıklama yer almış ardından "Aile, bir hücre gibidir. Çünkü toplumun tüm özelliklerini taşıyan, canlı bir yapıdır" "Aile bir duvar gibidir. Çünkü ben ne yapmaya kalksam beni sınırlar" şeklinde bir olumlu bir olumsuz örnek yer almıştır. Açıklama ve örneklerin ardından katılımcıların özel eğitimde iş birliğine ilişkin metaforik algıllarının belirlenmesi için "Özel eğitimde iş birliği.............................gibidir, çünkü .." şeklinde yarı yapılandırılmıss soru yer almıştır. "Metaforik Algı Anketi” iki farklı alan uzmanına sunularak anketin uygunluğu hakkında görüş alınmıştır. İlk uzman anket formuna bir olumlu örneğin yanına bir de olumsuz örnek konulması yönünde fikir beyan etmiştir. Görüş doğrultusunda ankete son hali verilmiştir. Her iki uzmanın olumlu görüşünün ardından anket son halini almıştır.

\section{Verilerin Toplanmas1}

Veri toplama sürecine başlanmadan gerekli onay ve izinler alınmıştır. Araştırmacılar, verileri toplamak için katılımcı özel eğitim öğretmeni adaylarının akademik danışmanlarından ders programları hakkında ön bilgi almışır. Tek seferde en fazla katılımcı sayısına ulaşabilmek için duyurular yapılmış ve katılımcıların aynı saatte bir arada olmaları sağlanmıştır. Belirlenen saatte araştırmacılar Metaforik Alg1 Anketi'ni katılımcılara dağıtmış, çalışma hakkında kısa bir bilgi vermiştir. Katılımcılardan kendilerine sunulan anketi dikkatle incelemeleri, anlamadıkları bir şey varsa sormaları istenmiştir. Katılımcılar tarafindan sorulan sorular cevaplanmıştır. Ardından katılımcılardan başkaları ile fikir alısverişi yapmadan, metafor ve gerekçe cümlelerinin her ikisini birlikte, okunaklı biçimde dağıtılan anket formuna yazmaları istenmiştir. Araştırmaya katılmaya gönüllü olmayan katılımcıların anket formunu boş bırakarak teslim edebilecekleri belirtilmiştir.

\section{Verilerin Analizi}

Araştırmanın verileri içerik analizi kullanılarak analiz edilmiştir. Bu çalışmada veriler toplandıktan sonra ilk aşamada 1) 107 öğretmen adayının doldurduğu anketler incelenmiş 14'ünün anketi uygun biçimde doldurmadığı anlaşılmış bu anketler analiz dışı bırakılmıştır, 2) Geriye kalan 93 ankete birden başlayarak 93'e kadar numara verilmiştir. İkinci aşamada metaforlar ve temalar belirlenerek kodlamalar yapılmıştır. Bu aşamada 1) Metaforlar belirlenmiş, 2) Temalar belirlenmiş, 3) Metaforların hangi temaya dahil olduğu belirlenmiş ve kodlanmıştır. Üçüncü aşama ise analiz ve yorum aşamasından oluşmuştur. Bu basamakta 1) Geçerlik ve güvenirlik analizi, 2) Elde edilen verilerin frekanslarının belirlenmesi 3) Elde edilen bulguların yorumlanması yapılmıştır (Büyükalan ve Yaylac1, 2018, s. 679; Dayı vd., 2020, s. 95; Ekici, 2016, s. 755; Yazar vd., 2017, s. 245).

\section{Geçerlik ve Güvenirlik Çalışmaları}

Bu çalışmanın geçerlik ve güvenirliğinin sağlanması için iç ve dış geçerlik çalışmaları yapılmıştır. Çalışmanın dış geçerliği amaçlı örneklem seçimi ile sağlanmıştır (Merriam, 2013, s. 199- 228). İç geçerliğin sağlanması için denetleme tekniği kullanılarak, araştırmada verilerin nasıl toplandığı ve kodlandığı ayrıntılı biçimde açıklanmışır. Ayrıca veri analizinin başından itibaren çelişkili ve uygun olmayan katılımcı ifadeleri analiz dışı bırakılarak veri toplama aşamasının uygun ve yeterli katılımdan oluşması sağlanmıştır. Bununla birlikte iç geçerliğin sağlanması için iki araştırmacı birbirinden bağımsız olarak kodlamalar yapmış ve kodlamalar tamamlandıktan sonra karşllaştırılmıştır. Bu karşılaştırma sonunda ortaya çıkan kod ve tema 
listesine son şekli verilmiştir. Veri analizinin güvenirliği; [Görüş birliği / (Görüş birliği + Görüş ayrllığ1) x 100] formülü ile hesaplanmıştır (Miles ve Huberman, 1994). Yapılan hesaplama sonunda çalısmanın güvenirliği \%95 olarak hesaplanmıştır.

\section{Bulgular}

$\mathrm{Bu}$ araştırmanın amacı, özel eğitim öğretmeni adaylarının "iş birliği” kavramılla ilgili geliştirdikleri metaforları analiz etmektir. Araştırma kapsamında öğretmen adaylarından özel eğitimde iş birliğine yönelik oluşturdukları metafor ve metaforun gerekçesini yazılı olarak ifade etmeleri istenmiştir. Bu bölümde özel eğitim öğretmeni adaylarının özel eğitimde iş birliği kavramı için oluşturdukları metaforlar, metaforların dahil edildiği temalar ve verilerin frekansları yer almaktadır. Çalışmaya katılan özel eğitim öğretmeni adaylarının özel eğitimde iş birliğine yönelik oluşturdukları metaforlar ve sıklık sıralamasına göre frekansları Tablo 1' de yer almaktadir.

Tablo 1. Katıllmolarn "İs Birliği" Kavramı İ̧̧in Olușturduklar Metaforlar

\begin{tabular}{|c|c|c|c|c|c|}
\hline $\begin{array}{c}\text { Metaforun } \\
\text { Sirasi }\end{array}$ & Metafor Adr & $\bar{f}$ & $\begin{array}{c}\text { Metaforun } \\
\text { Sirasi }\end{array}$ & Metafor Adr & $\bar{f}$ \\
\hline 1 & Zincir halkası & 6 & 29 & Düğün evi & 1 \\
\hline 2 & Yapboz parças1 & 5 & 30 & Fabrika & 1 \\
\hline 3 & A ğacın/ bitkinin kökleri & 4 & 31 & Fermuar & 1 \\
\hline 4 & Yapboz & 3 & 32 & Futboldaki orta sahalar & 1 \\
\hline 5 & İnşaat yapmak & 3 & 33 & Geometrik şekil & 1 \\
\hline 6 & Zincir & 2 & 34 & Gök kuşağı & 1 \\
\hline 7 & Ăgaç & 2 & 35 & İmece & 1 \\
\hline 8 & Aile & 2 & 36 & Kale & 1 \\
\hline 9 & Anahtar ve kilit & 2 & 37 & Karıncaların kışa hazırlanması & 1 \\
\hline 10 & Bina & 2 & 38 & Kilit taşı & 1 \\
\hline 11 & Dişliler & 2 & 39 & Kömürü elmas yapmak & 1 \\
\hline 12 & Duvar & 2 & 40 & Köprü & 1 \\
\hline 13 & Evin temeli & 2 & 41 & Kurufasulye pilav & 1 \\
\hline 14 & Futbol takımı & 2 & 42 & Kuş yuvası & 1 \\
\hline 15 & Kan & 2 & 43 & Kuşun uçması & 1 \\
\hline 16 & Organlar & 2 & 44 & Makinanın parçaları & 1 \\
\hline 17 & Örümcek ağ1 & 2 & 45 & Mekanizma & 1 \\
\hline 18 & Parmaklar & 2 & 46 & Merdiven basamakları & 1 \\
\hline 19 & Saat & 2 & 47 & Mutualist ilişki & 1 \\
\hline 20 & Tren vagonu & 2 & 48 & Mücadele & 1 \\
\hline 21 & Vücut & 2 & 49 & Örgü & 1 \\
\hline 22 & Anne & 1 & 50 & Şeker & 1 \\
\hline 23 & Ar1 kovanı & 1 & 51 & Şirket & 1 \\
\hline 24 & Bal peteği & 1 & 52 & Tahterevalli & 1 \\
\hline 25 & Dağa tırmanmak & 1 & 53 & Tekerlek & 1 \\
\hline 26 & Bulunmaz Hint kumaşı & 1 & 54 & Tereyağll iskender & 1 \\
\hline 27 & Çiçeğin açması & 1 & 55 & Tuz & 1 \\
\hline 28 & Domino taşları & 1 & 56 & Düğüm & 1 \\
\hline Toplam & & & & & 93 \\
\hline
\end{tabular}

Tablo 1 incelendiğinde katılımcıların toplam 93 görüş belirterek, 56 farklı metafor ürettikleri görülmektedir. Özel eğitim öğretmeni adaylarının en sık belirttikleri metaforların "zincir halkası, yapboz parçası, bir ağacın/ bitkinin kökleri, yapboz, bina/ inşaat yapmak olduğu görülmektedir. Özel eğitimde iş birliği kavramı ile en sık benzetilen kavramlar zincir halkası $(f=6)$ ve yapboz parçası olmuştur $(f=5)$. Zincir halkası ve yapboz parçaları yapı gereği devamlılık arz etmesi gereken, bir tanesinin göreve ilişkin işlevini yerine getirmediği ya da eksik olduğu zaman bütünün eksik çalısmasına ya da hiç çalışmamasına neden olabilecek kavramlardır. Bu bağlamda öğretmen adaylarının özel eğitimde iş birliği kavramını zincir halkaları ve yapboz parçaları ile iş birliğinde yer alan her bir işbirlikçinin görev ve sorumluluklarını yerine getirmesi, bir paydaşın bilgi ya da beceri eksikliğinin tüm işleyişi etkileyebileceği ile ilişkilendirildiği söylenebilir. Özel eğitim öğretmeni adaylarının en sık ürettiği diğer üç metafor ise yapboz $(f=4)$, bir ağacın/ bitkinin kökleri $(f=3)$, bina/ inşaat yapmak $(f=3)$ olduğu görülmektedir. Bu metaforlar incelendiğinde ise yapı olarak birden fazla parçadan ya da işten oluşan sağlam, dikkatle planlanması 
gereken işlemler içeren, bir sistemin çalışabilmesi ve sağlıklı olması için gerekli olan kavramlar olduğu görülmektedir. Öğretmen adaylarının bu metaforları özel eğitimde iş birliğinin önemi ve yapısı ile bağdaştırdığ1 düşünülebilir. Katılımcıların ürettiği 16 metaforun (bina/ inşaat yapmak, zincir, ağaç, aile, anahtar ve kilit, bina, dişliler, duvar, evin/ binanın temeli, futbol takımı, kan, organlar, örümcek ağı, parmaklar, saat, tren/ tren vagonu, vücut) sıklı̆ının iki olduğu görülmektedir. Bu metaforlar dikkatli incelendiğinde ise bir arada çalışan, işleyen ya da etkileşim halinde olan sistemlere ilişskin benzetmelerin yoğunlukta olduğu görülmektedir. Katılımcıların ürettiği son 24 metaforun ise (anne, arı kovan1, bal peteği, bir dağa tırmanmak, bulunmaz Hint kumaşı, çiçeğin açması, domino taşları, düğüm, köprü, kuru fasulye pilav, kuş yuvası, kuşun uçması, makinanın parçaları, mekanizma, merdiven basamakları, mutualist bir ilişki, mücadele, örgü, şeker, şirket, tahterevalli, tekerlek, tereyağlı iskender, tuz) sıklığının bir olduğu görülmektedir. Katılımcıların özel eğitimde iş birliği kavramına ilişkin ürettiği metaforlara ait kelime bulutu Şekil 1'de yer almaktadır.

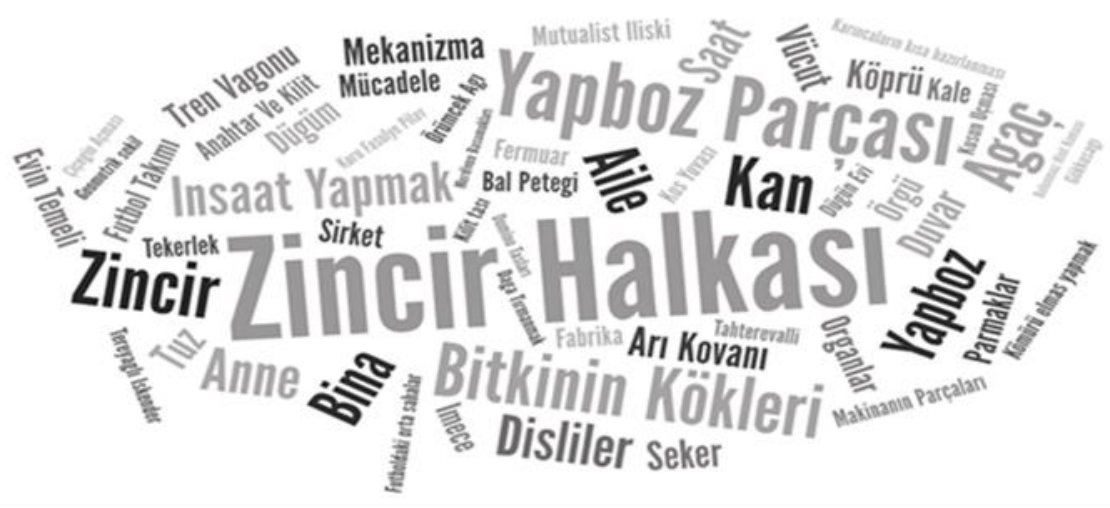

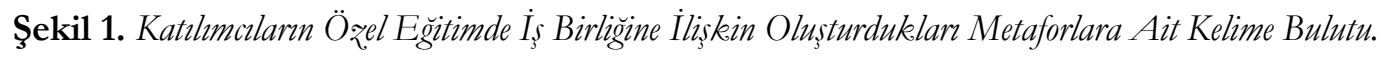

Çalışma kapsamında ikinci olarak özel eğitim öğretmeni adaylarının özel eğitimde iş birliğine ilişkin metaforlarının ortak özellikleri doğrultusunda ait oldukları temaların belirlenmesi amacı güdülmüştür. Tablo 2'de öğretmen adaylarının ürettiği metaforların ait olduğu kategoriler ve yüzdeleri bulunmaktadır.

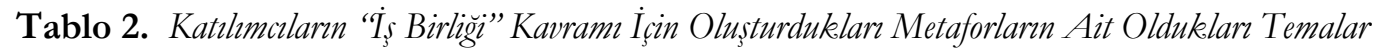

\begin{tabular}{|c|c|c|c|}
\hline Tema & $\bar{f}$ & $\%$ & İlişkilendirilen Metaforlar \\
\hline $\begin{array}{l}\text { İş birliğinin yapısı } \\
\text { bakımından }\end{array}$ & 33 & 35.48 & $\begin{array}{l}\text { yapboz, ağaç, dişliler, bir dağın zirvesine tırmanmak, aile, tahterevalli, } \\
\text { gökkuşağı, geometrik şekil, yapboz parçaları, düğün evi, tren vagonu, şirket, } \\
\text { saat, bina, örümcek ağı, inşaat yapmak, büyük bir mücadele, parmaklar, zincir } \\
\text { halkaları zincir, anahtar ve kilit, zincir, kale, saat, düğüm, bal peteği, mutualist } \\
\text { bir ilişki }\end{array}$ \\
\hline $\begin{array}{l}\text { İş birliğine yönelik } \\
\text { tehditler/ başarısını } \\
\text { olumsuz etkileyen etmenler } \\
\text { bakımından }\end{array}$ & 20 & 21.50 & $\begin{array}{l}\text { yapboz parçaları, parmaklar, domino taşları, örgü, tren vagonu, zincir halkaları, } \\
\text { makine parçaları, fermuar, vücut, dişli, bulunmaz hint kumaşı, anahtar ve kilit, } \\
\text { organlar, inşaat yapmak, arı kovanı }\end{array}$ \\
\hline $\begin{array}{l}\text { İş birliğinin önemi } \\
\text { bakımından }\end{array}$ & 19 & 20.43 & $\begin{array}{l}\text { bir ağacın/ bitkinin kökleri, tuz, şeker, tekerlek, futboldaki orta sahalar, evin } \\
\text { temeli, kan, kilit taşı, duvar, anne, dayanacak destek, kural, kömürü elmas } \\
\text { yapmak. }\end{array}$ \\
\hline $\begin{array}{l}\text { İş birliğinin gereklilikleri } \\
\text { bakımından }\end{array}$ & 15 & 16.12 & $\begin{array}{l}\text { inşaat yapmak, fabrika, futbol takımı, halat çekme oyunu, yapboz, bir kuşun } \\
\text { uçuşu, imece, mekanizma, bir bitkinin çiçek açması, kuru fasulye pilav, } \\
\text { tereyağlı iskender, aile, zincir, karıncaların kışa hazırlık yapması }\end{array}$ \\
\hline $\begin{array}{l}\text { İşbirliğinin amacı } \\
\text { bakımından }\end{array}$ & 6 & 6.45 & bülbül yuvası, şemsiye, merdiven, köprü, organlar, bal peteği \\
\hline Toplam & 93 & & 100 \\
\hline
\end{tabular}

Tablo 2 incelendiğinde katılımciların ürettiği metaforları 5 farklı tema altında toplandığ görülmektedir. $\mathrm{Bu}$ temalar sıklık sırasına göre iş birliğinin yapısı $(\mathrm{f}=33, \% 35.48)$, iş birliğine yönelik tehditler ve başarısını olumsuz etkileyen etmenler $(\mathrm{f}=20, \% 21.5)$ ve iş birliğinin önemi ( $\mathrm{f}=19, \% 20.43)$, iş birliğinin gereklilikleri ( $\mathrm{f}=15, \% 16.12$ ), iş birliğinin amacı bakımından ( $\mathrm{f}=6, \% 6.45$ ) olarak sıralanmaktadır. Tablo 2'de görüldüğü üzere özel eğitim öğretmeni adayları iş birliğine yönelik metaforlarını en fazla iş birliğinin yapısına yönelik olarak geliştirmişlerdir. Katılımcıların iş birliğinin yapısı bakımından ürettikleri metaforlar ve gerekçeleri Tablo 3'te incelenmektedir. 
Tablo 3. Katıllmollarn "İs Birliğinin Yapısı" Bakımından Olusturduklarn Metaforlar ve Gerekceleri

\begin{tabular}{|c|c|}
\hline Tema & Metafor ve gerekçesi \\
\hline & 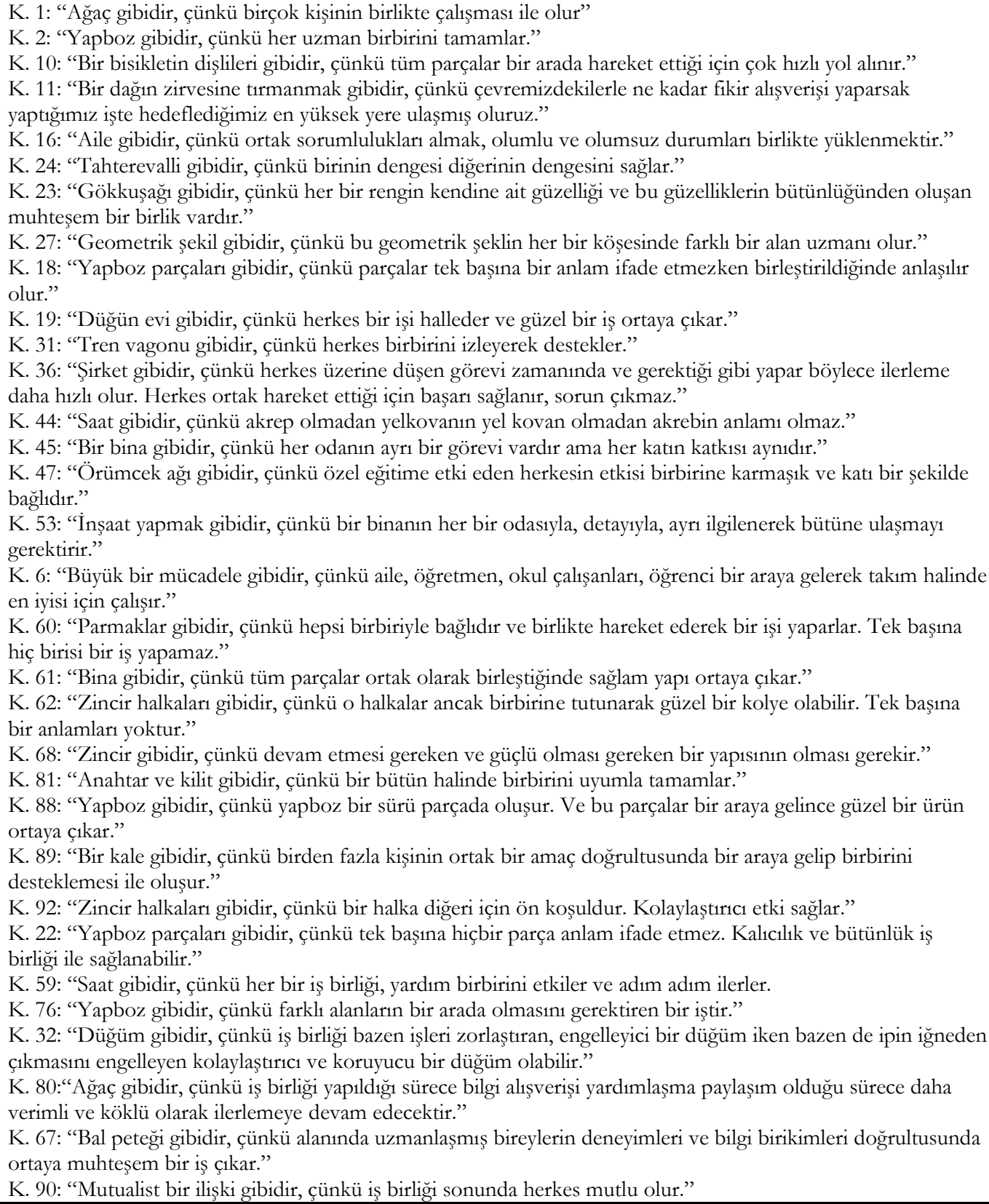 \\
\hline
\end{tabular}

Katılımcıların iş birliğinin yapısına yönelik "yapboz, ağaç, dişliler, bir dağın zirvesine tırmanmak, aile, tahterevalli, gökkuşağı, geometrik şekil, yapboz parçaları, düğün evi, tren vagonu, şirket, saat, bina, örümcek ağı, inşaat yapmak, büyük bir mücadele, parmaklar, zincir halkaları zincir, anahtar ve kilit, zincir, kale, saat, düğ̈̈m, bal peteği” metaforlarını ürettikleri görülmektedir. Üretilen metaforlar ve gerekçeleri ayrıntılı olarak incelendiğinde ise iş birliğinin birçok uzmanın bir arada çalışması, ortaya çıkan sonuçların kalitesi, bir arada çalışmanın hızlı ve etkili sonuçlar vereceği yönünde gerekçelerle ilişkilendirildiği görülmektedir. Örneğin bir katılımc1 (K. 1) iş birliğine ilişkin "Ağaç gibidir, çünkü birçok kişinin birlikte çalışması ile olur" şeklinde metafor ve gerekçe belirtirken, başka bir katılımc1 (K. 23) "Gökkuşağı gibidir, çünkü her bir rengin kendine ait güzelliği ve bu güzelliklerin bütünlügünden oluşan muhteşem bir birlik vardır." Başka bir katılımcı ise (K. 10) "Bir bisikletin dişlileri gibidir, çünkü tüm parçalar bir arada hareket ettiğgi için çok hızlı yol alınır." ifadesini kullanmıştır. Diğer taraftan bir katılımcının (K. 32) "Dügüum gibidir, çünkü iş birliği bazen işleri zorlaştıran, engelleyici bir dügüm iken bazen de ipin iğneden çıkmasını engelleyen kolaylaştırıcı ve koruyucu bir düğüm olabilir.” şeklindeki ifadesi iş birliğinin kendi içinde zorlukları olan bir süreçken, bazı durumlarda da zorlukları çözmek için kullanılan bir süreç olduğunu 
düşündürmektedir. Katıllımcıların "iş birliğini engelleyen faktörler ve iş birliğine yönelik tehditler" oluşturdukları metafor ve gerekçeleri Tablo 4'te yer almaktadır.

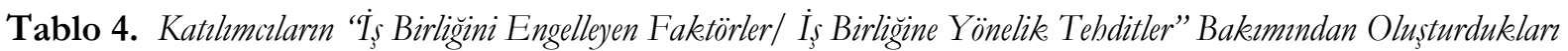
Metafor ve Gerekeseleri

\begin{tabular}{|c|c|}
\hline Tema & Metafor ve gerekçesi \\
\hline $\begin{array}{l}\text { İş birliğini } \\
\text { engelleyen } \\
\text { faktörler/ iş } \\
\text { birliğine } \\
\text { yönelik } \\
\text { tehditler }\end{array}$ & 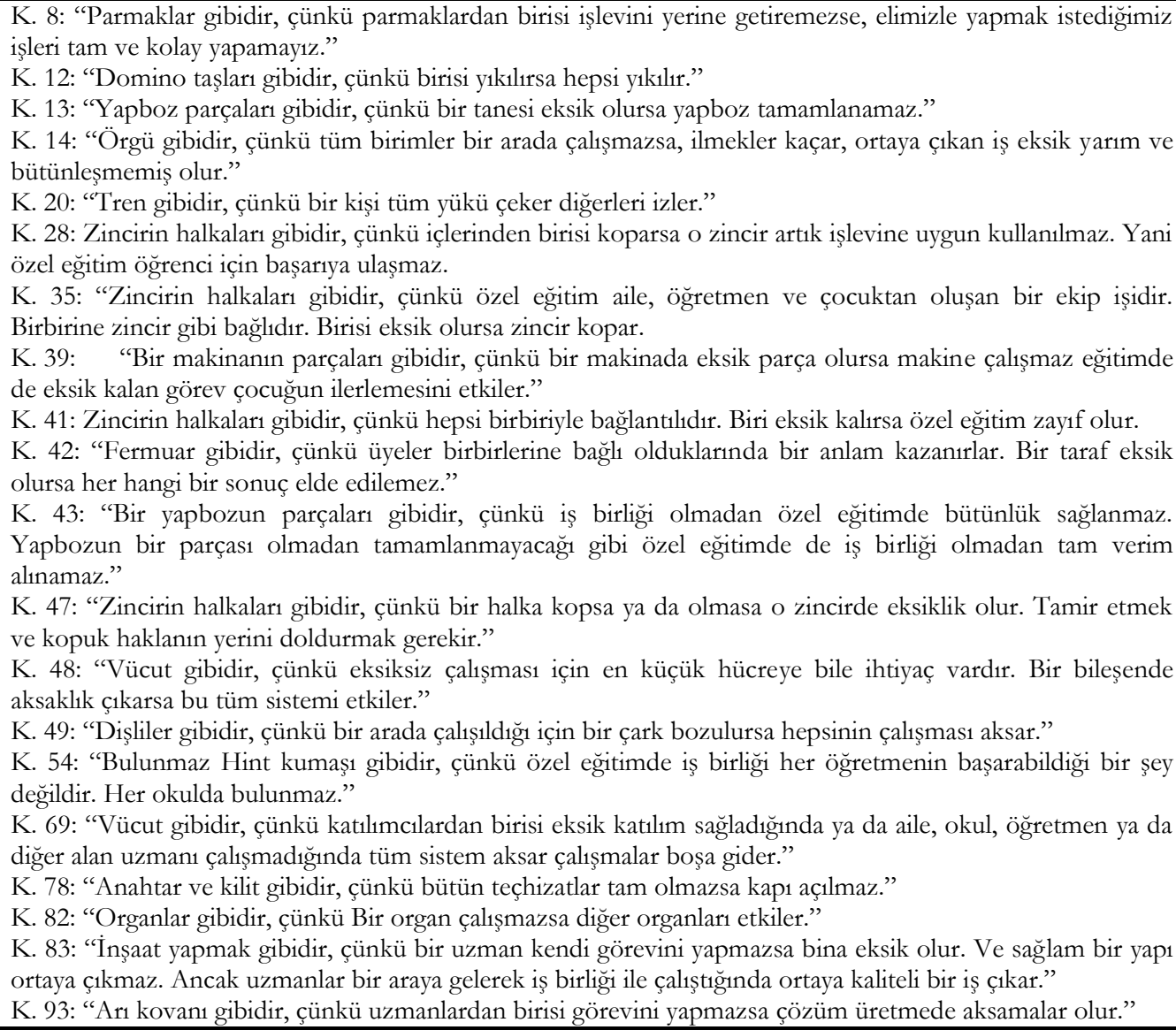 \\
\hline
\end{tabular}

Tablo 4 incelendiğinde katılımcıların iş birliğine yönelik tehditler teması altında oluşturdukları metaforların yapboz parçaları, parmaklar, domino taşları, örgü, tren vagonu, zincir halkaları, makine parçaları, fermuar, vücut, dişli, bulunmaz Hint kumaşı, anahtar ve kilit, organlar, inşaat yapmak, arı kovanı olarak sıralandığı görülmektedir. Bu metaforların genel olarak bir ya da birkaç öğeden oluşan kavramlar olduğu görülmektedir. Bu öğelerden bir ya da birkaçının eksikliği ya da çalışmaması durumu bütünün çalışmasını engelleyecek nitelikte olduğu görülmektedir. Nitekim katılımcıların metaforları ve gerekçeleri ayrıntılı olarak incelendiğinde iş birliğinde yer alan işbirlikçi ya da uzmanların eksik çalışması ya da çalısmaması durumunda tüm süreci olumsuz olarak etkileyebileceği yönünde olduğu görülmektedir.

Örneğin bir katıllımcı özel eğitimde iş birliğini örgüye benzeterek (K. 14) "Örgü gibidir, çünkü tüm birimler bir arada çalışmazsa, ilmekler kaçar, ortaya çıkan iş eksik yarım ve bütünleşmemiş olur." şeklinde gerekçe sunmuştur. Başka bir katılımcı ise (K. 83) "İnşaat yapmak gibidir, çünkü bir uzman kendi görevini yapmazsa bina eksik olur ve sağlam bir yapı ortaya çıkmaz. Ancak uzmanlar bir araya gelerek iş birliği ile çalıştığında ortaya kaliteli bir iş çıkar.” şeklinde fikir belirtmiştir. Katıllımcılardan birisi ise özel eğitimde iş birliğini yapboz parçaları ile özdeşleştirerek iş birliğinde yer alan paydaşların niteliği ile iş birliğinin kalitesi arasındaki ilişkiye dikkat çekmiştir ve (K. 43) "Bir yapbozun parçaları gibidir, çünkü iş birliği olmadan özel eğitimde bütünlük sağlanmaz. Yapbozun bir parçası olmadan tamamlanmayacağı gibi özel eğitimde de iş birliği olmadan tam verim alınamaz." şeklinde metafor ve gerekçesini sunmuştur. Başka bir katıllımcı ise (K. 54) "Bulunmaz Hint kumaşı gibidir, çünkü özel eğitimde iş birliği her öğretmenin başarabildiği bir şey değildir. Her okulda bulunmaz." şeklinde metafor üreterek metaforunu iş birliğinin okul ortamı ve öğretmen değişkenleri ile ilişkilendirmiştir. Katıllımcıların iş birliğinin önemine yönelik oluşturdukları metafor ve gerekçeleri Tablo 5’te yer almaktadır. 
Tablo 5. Katullmcilarn "İs Birliğinin Önemi" Bakemmndan Olusturduklarn Metafor ve Gerekeceleri

\begin{tabular}{|c|c|}
\hline Tema & Metafor ve gerekçesi \\
\hline $\begin{array}{l}\text { İş birliğinin } \\
\text { önemi }\end{array}$ & 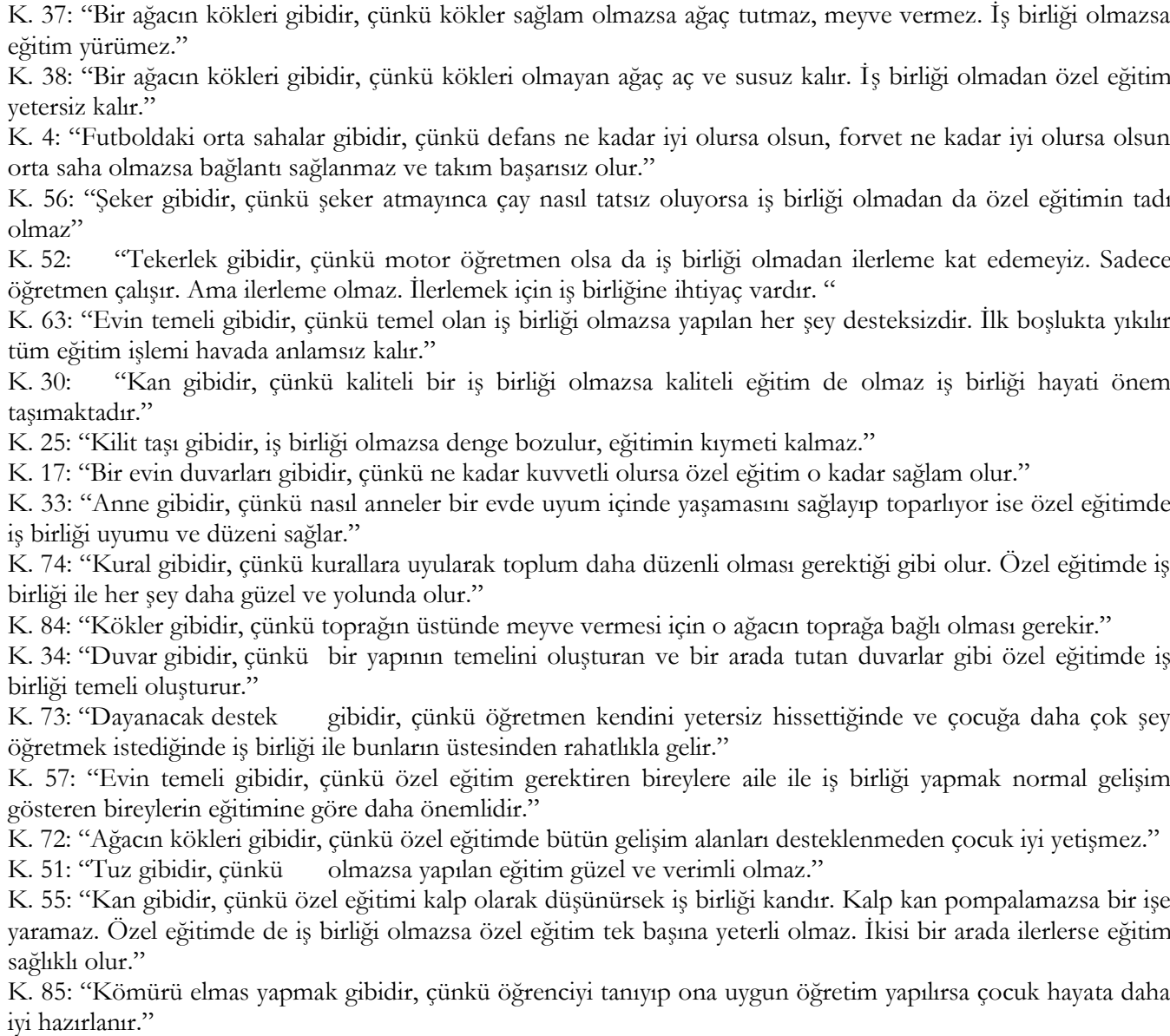 \\
\hline
\end{tabular}

Tablo 5 incelendiğinde katılımcıların "iş birliğinin önemi bakımından" oluşturdukları metaforların "bir ağacın/ bitkinin kökleri, tuz, şeker, tekerlek, futboldaki orta sahalar, evin temeli, kan, kilit taşı, duvar, anne, dayanacak destek, kural, kömürü elmas yapmak" olduğu görülmektedir. Oluşturulan metaforların çoğunluğunun temel özellikleri incelendiğinde, bir sistemin yaşamasını, ayakta durmasını ve devamlılığını sürdürmesi için gerekli olan kavramlardan oluştuğu görülmektedir. Örneğin iş birliğinin özel eğitimdeki hayati işlevini belirtmek amacıyla bir katılımcı (K. 30) "Kan gibidir, çünkü kaliteli bir iş birliği olmazsa kaliteli eğitim de olmaz iş birliği hayati önem taşımaktadır." ifadesini kullanırken, başka bir katılımcı (K. 37) "Bir ağacın kökleri gibidir, çünkü kökler sağlam olmazsa ağaç tutmaz, meyve vermez. İş birliği olmazsa eğitim yürümez." şeklinde, başka bir katılımcı ise (K. 38) "Bir ağacın kökleri gibidir, çünkü kökleri olmayan ağaç aç ve susuz kalır. İş birliği olmadan özel eğitim yetersiz kalır.” benzetmesini kullanmıştır. İş birliğinin öğretmen açısından önemini vurgulayan bir katıllımcı (K. 73) "Dayanacak destek gibidir, çünkü ögretmen kendini yetersiz hissettiğinde ve çocuğa daha çok şey öğretmek istediğinde iş birliği ile bunların üstesinden rahatlıkla gelir." ifadesini kullanırken, başka bir katılımcı ise iş birliğinin çocuk tarafındaki çıktılarına vurgu yaparak (K. 85) "Kömürü elmas yapmak gibidir, çünkü öğrenciyi tanıyıp ona uygun öğretim yapılırsa çocuk hayata daha iyi hazırlanır." şeklinde metaforunu gerekçelendirmiştir. Katılımcıların iş birliğinin gereklilikleri bakımından oluşturdukları metafor ve gerekçeleri Tablo 6'da yer almaktadır. 
Tablo 6. Katılumclarm “İs Birlig̈inin Gereklilikleri Bakımundan” Olușturduklar Metafor ve Gerekçeleri

\begin{tabular}{|c|c|}
\hline Tema & Metafor ve gerekçesi \\
\hline $\begin{array}{l}\text { İş birliğinin } \\
\text { gereklilikleri }\end{array}$ & 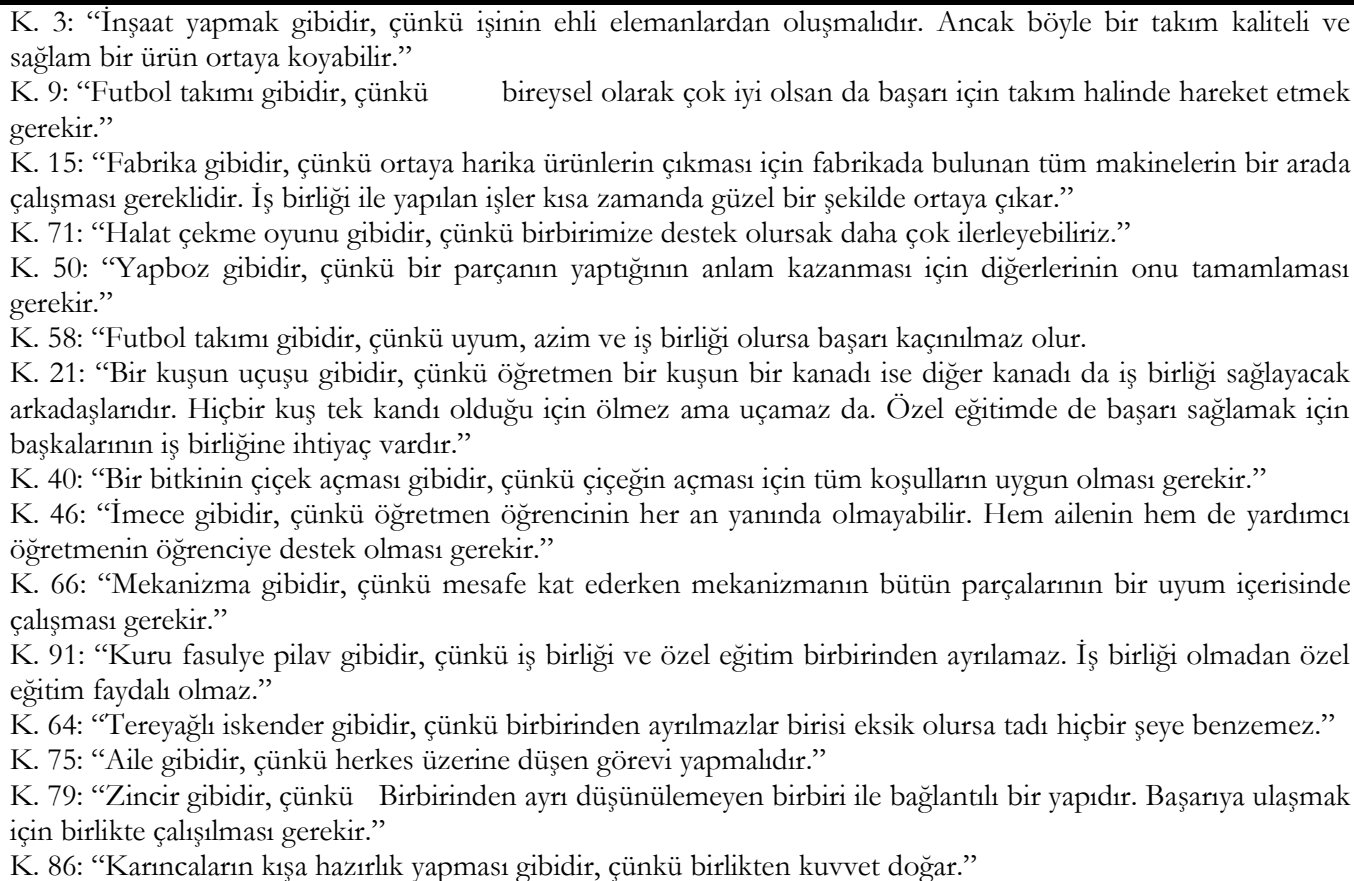 \\
\hline
\end{tabular}

Tablo 6 incelendiğinde katılımcıların "iş birliğinin gereklilikleri bakımından" "inşaat yapmak, fabrika, futbol takımı, halat çekme oyunu, yapboz, bir kuşun uçuşu, imece, mekanizma, bir bitkinin çiçek açması, kuru fasulye pilav, tereyağlı iskender, aile, zincir, karıncaların kışa hazırlık yapması" metaforlarını ürettikleri görülmektedir. Oluşturulan metaforların ortak özellikleri incelendiğinde bir arada çalışmayı gerektiren, ortak amaç için çalışan, uyum içinde olan ve bir araya geldiğinde anlamlı bütün oluşturan kavramlardan oluştuğu görülmektedir. İş birliğinin gerekliliklerinden sorumluluk paylaşımını bir katılımcı (K. 75) "Aile gibidir, çünkü herkes üzerine düşen görevi yapmalıdır.” şeklinde benzetmiştir. Katılımcılardan bazıları (K. 79): "Zincir gibidir, çünkü birbirinden ayrı düşünülemeyen birbiri ile bağlantılı bir yapıdır. Başarıya ulaşmak için birlikte çalışılması gerekir." (K. 9) "Futbol takımı gibidir, çünkü bireysel olarak çok iyi olsan da başarı için takım halinde hareket etmek gerekir.", (K. 15) "Fabrika gibidir, çünkü ortaya harika ürünlerin çıkması için fabrikada bulunan tüm makinelerin bir arada çalışması gereklidir. İş birliği ile yapılan işler kısa zamanda güzel bir şekilde ortaya çıar.” şeklinde metafor ve gerekçesini sunarken iş birliğinin başarısı için bir arada çalışmanın gerekliliğine vurgu yapmıştır. Katılımcıların iş birliğinin amaçlanı bakımından oluşturdukları metafor ve gerekçeleri Tablo 7'de yer almaktadır.

Tablo 7. Katullmollarn "İs Birliğinin Amaşlar Bakımından" Olușturduklarn Metafor ve Gerekegeleri

\begin{tabular}{|c|c|}
\hline Tema & Metafor ve gerekçesi \\
\hline $\begin{array}{l}\text { İş birliğinin } \\
\text { amaçları }\end{array}$ & $\begin{array}{l}\text { K. 5: "Bülbül yuvası gibidir, çünkü özenle birleştirilen malzemeler öğrenciyi geliştirmeyi hedef alır." } \\
\text { K. 70: "Şemsiye gibidir, çünkü iş birliği yapmak öğrenciyi yaşayacağı olumsuz durumlardan korur." } \\
\text { K. 26: "Merdiven basamakları gibidir, çünkü her biri el birliği ile bireyi yukarı taşımak amaciyla toplanır." } \\
\text { K. 29: "Köprü gibidir, çünkü eğer disiplinler arası iş birliği olmazsa öğretmen ögrenciye ulaşamaz, özel eğitim } \\
\text { amacına ulaşmaz." } \\
\text { K. 7: "Organlar gibidir, çünkü iş birliği yapanlar öğrencinin faydası, rahatı ve başarısı için çalışır. } \\
\text { K. 77: "Bal peteği gibidir, çünkü bütün eğitimciler öğrenciye yeni bilgi ve becerileri öğrettikçe öğrenci } \\
\text { gelişir." }\end{array}$ \\
\hline
\end{tabular}

Tablo 7 incelendiğinde katılımcıların "iş birliğinin amaçları bakımından" oluşturdukları metaforların bülbül yuvası, şemsiye, merdiven, köprü, organlar, bal peteği şeklinde sıralandığı görülmektedir. Katılımcıların ürettiği metaforlar ayrıntılı olarak incelendiğinde koruyucu, geliştirici, ulaştırıcı özelliklere sahip kavramlardan oluştuğu dikkat çekmektedir. Önneğin bir katıllımcı iş birliği ile şemsiye arasında benzetim yaparak (K. 70) "Ş̧emsiye gibidir, çünkü iş birliği yapmak öğrenciyi yaşayacağ olumsuz durumlardan korur." şeklinde metaforunu ve gerekçesini ifade ederken başka bir katıllımcı (K. 29) "Köprü gibidir, çünkü eğer disiplinler arası iş birliği olmazsa öğretmen öğrenciye ulaşamaz, özel eğitim amacina ulaşmaz." ifadesiyle iş birliğinin çocuğa hizmet ulaştırmak için gerekli olduğunu ifade etmiştir. Başka bir 
katıllımcı ise iş birliğini organlara benzeterek (K. 7) "Organlar gibidir, çünkü iş birliği yapanlar öğrencinin faydası, rahatı ve başarısı için çalışır." şeklinde gerekçelendirmiştir.

\section{Tartışma, Sonuç ve Öneriler}

Bu çalısmada özel eğitim öğretmeni adaylarının özel eğitimde iş birliği kavramına yönelik algılarının, ürettikleri metaforlar yoluyla belirlenmesi amaçlanmışır. Çalışma sonunda 93 öğretmen adayının özel eğitimde iş birliği kavramı ile 56 farklı metafor arasında benzetme yaptı̆̆1, yaptıkları benzetimlerin ise 5 farklı tema altında gruplandığı sonucuna ulaşılmıştır. Araştırmada ilk olarak "Özel eğitim öğretmeni adaylarının "iş birliğı" kavramılla ilgili oluşturdukları metaforlar nelerdir?" sorusuna cevap aranmıştır. Çalışmanın sonunda özel eğitim öğretmeni adaylarının iş birliği kavramını en fazla zincir halkası, yapboz parçası, ağacın/ bitkinin kökleri, yapboz ve inşaat yapmak kavramlanna benzettikleri sonucuna ulaşılmıştır. Katılımcıların ürettikleri metaforlar ve gerekçeleri ayrıntılı olarak incelendiğinde, özel eğitimde iş birliği kavramını devamlılık, sağlamlık, bir yapının ya da sistemin devamı için gerekli olan, bir araya geldiğinde anlamlı bir bütün oluşturan kavramlara benzettikleri görülmüştür.

Alanyazında yapılan çalışmalarda iş birliği kavramı pek çok özellik ve kendine has esasları olan bir kavram olarak tanımlandığı bilinmektedir (Cook ve Friend, 1991, s. 6; Cook ve Friend, 2010, s. 1; Friend ve Cook, 1992). Alanyazın incelendiğinde iş birliği kavramının birden fazla eş işbirlikçinin bir amaç doğrultusunda bir araya gelerek gönüllü olarak çalıștıkları ve karar aldıkları etkileşime dayalı bir yaklaşım olarak tanımlandığı görülmektedir. Bunun yanı sıra iş birliğinin oluşması ve devamlilığının sağlanması için paydaşların ortak bir hedef doğrultusunda eşit, gönüllü, paylaşımc1, çalışma ve karar almada ortak sorumluluklar almas1 (Cook ve Friend, 1991, s. 6; Cook ve Friend, 2010, s. 1; Friend ve Cook, 1992), birden fazla kişi ile etkileşim kurma, etkili problem çözme ve sorumluluk alma gibi becerileri sahip olması gerekmektedir (Thousand vd., 2006, s. 239; Winn ve Blanton, 2005, s. 1). Çalışmaya katılan özel eğitim öğretmeni adaylarının ürettikleri metaforların alanyazında iş birliğinin tanımlanması için kullanılan gereklilik ve esaslarla örtüştüğü söylenebilir.

Çalışmada ikinci olarak özel eğitim öğretmeni adaylarının ürettikleri metaforların ortak özellik bakımından hangi temalar alında toplanmaktadır?” sorusuna cevap aranmıştır. Bu soru doğrultusunda elde edilen bulgular ise çalışmaya katılan özel eğitim öğretmeni adaylarının ürettiği metaforların iş birliğinin yapısı, iş birliğine yönelik tehditler ve iş birliğinin başarısını olumsuz etkileyen etmenler, iş birliğinin önemi, iş birliğinin gereklilikleri ve amacı olmak üzere beş tema altında toplandığını göstermiştir. İkinci amaç doğrultusunda katılımcıların iş birliğinin yapısına yönelik oluşturdukları metaforlar "yapboz, ağaç, dişliler, bir dağın zirvesine tırmanmak, aile, tahterevalli, gökkuşağı, geometrik şekil, yapboz parçaları, dügün evi, tren vagonu, şirket, saat, bina, örümcek ağı, inşaat yapmak, büyük bir mücadele, parmaklar, zincir halkaları zincir, anahtar ve kilit, zincir, kale, saat, düğüm, bal peteği’” şeklinde sıralanmıştır.

Katılımcıların iş birliğinin gerekliliklerine ilişkin ise "inşaat yapmak, fabrika, futbol takımı, halat çekme oyunu, yapboz, bir kuşun uçuşu, imece, mekanizma, bir bitkinin çiçek açması, kuru fasulye pilav, tereyağı iskender, aile, zincir, karıncaların kışa hazırlık yapması" gibi metaforlar oluşturdukları sonucuna ulaşılmışır. Katılımcıların iş birliğinin kalitesini olumsuz etkileyen ve iş birliğine yönelik tehditlerle ilgili "yapboz parçaları, parmaklar, domino taşları, örgü, tren vagonu, zincir halkaları, makine parçaları, fermuar, vücut, dişli, bulunmaz Hint kumaşı, anahtar ve kilit, organlar, inşaat yapmak, arı kovanı" metaforlarını ürettikleri görülmüştür. Bu kavramlar ayrıntılı olarak incelendiğinde birden fazla öğeden oluşan ve öğelerden birinin niteliğinin diğer öğelerin çalışmasını etkileyebilecek yapıda oldukları görülmektedir. Katılımcıların iş birliğinde yer alan işbirlikçi ya da uzmanların eksik çalışması ya da çalışmaması durumunda tüm süreci olumsuz olarak etkileyebileceği yönünde gerekçeler ürettikleri görülmüştür. Alanyazında yapılan çalışmalarda ise iş birliğinin kalitesinin öğretmen ve yardımcı personelin becerilerinden, okulun ve idarecilerin yapısından (Biggs vd., 2016, s. 256), öğretmenlerin ortak bir amac1, felsefeyi ve dili paylaşmalarından (Carter vd., 2009, s. 60), hizmet öncesinde ve sonrasında aldıkları eğitimden (Brownell vd., 2006, s. 169; Lynch vd., 2014, s. 1; Vuran vd., 2017, s. 165; Zagona vd., 2017, s. 163) etkilendiği sıklıkla vurgulanmaktadır. Bunun yanı sıra yapılan çalışmalarda özel eğitim alanında çalışan uzmanların iş birliği becerilerinin nitelik ve niceliğinin uygun olmadığını gösteren çalışmalar da mevcuttur (Elçi, 2019; Yener, 2019). Alanyazında var olan çalışmalar ile bu çalışmadan elde edilen bu sonucun, özel eğitim öğretmeni adaylarının iş birliğine ilişkin bilgi ve becerilerinin artırılması için hizmet öncesi ve hizmet sonrası eğitimlere bir kez daha vurgu yaptığı düşünülmektedir. 
Çalışmada katılımcıların bir sistemin yaşamasını, ayakta durmasını ve devamlılı̆̆ını sürdürmesi için gerekli bir kavram olarak iş birliğini önem bakımından "bir ağacın/ bitkinin kökleri, tuz, şeker, tekerlek, futboldaki orta sahalar, evin temeli, kan, kilit taşı, duvar, anne, dayanacak destek, kural, kömürü elmas yapmak" metaforlarına benzettikleri sonucuna ulaşılmıştır. Katılımcıların işbirlikçi çalışmalar sayesinde verilecek hizmetlerin daha kaliteli, hızlı ve verimli bir biçimde ulaştırılması açısından önemli olduğuna yönelik gerekçeler sundukları görülmüştür. Katılımcıların bu gerekçeleriyle paralel olarak alanyazında iş birliği doğası gereği kendi içinde zorlukları olan bir süreç olduğu, ancak birden fazla alanda uzmanının bilgi paylaşımını, üretilen çözümlerin birden fazla göz tarafindan incelenmesini içerdiği için hata yapma olasıllı̆ını düşürdüğü vurgulanmaktadır (Winn ve Blanton, 2005, s. 1). Bu nedenle işbirlikçi yaklaşımların özellikle özel eğitim alanında daha fazla tercih edildiği bilinmektedir (Hunt vd., 2003, s. 315).

Çalışmada son olarak katılımcıların özel eğitimde iş birliğinin amaçlarına yönelik metaforlarının "bülbül yuvası, şemsiye, merdiven, köprü, organlar, bal peteği" şeklinde sıralandığ1 sonucuna ulaşılmıştır. Katılımciların gerekçelerinin, iş birliği aracilığı ile çocuğun olumsuz durumlardan korunabileceği, çocuğun hizmet almasının kolaylaşacağı, çocuğun mevcut durumundan daha iyi duruma ulaşacağı şeklinde ifade edildiği görülmüştür. Katılımcıların açıklamalarında çoğunlukla iş birliğinin çocuğa yönelik çözümlere vurgu yaptı̆̆1 sonucuna ulaşılmışıır. Nitekim alanyazında yapılan çalışmalarda da işbirlikçci yaklaşımları benimseyen okullarda öğrenci başarısının arttığını gösteren çalışmalar mevcuttur (Caron ve McLaughlin, 2002, s. 285; Hunt vd. 2003, s. 315).

Özel eğitim öğretmeni adaylarının özel eğitimde iş birliği kavramına yönelik metaforik algıları, ürettikleri metaforlar yoluyla belirlenmesinin amaçlandığı bu çalışma sonunda 93 öğretmen adayının özel eğitimde iş birliği kavramı ile 56 farklı metafor arasında benzetme yaptı̆̆1, yaptıkları benzetimlerin ise 5 farklı tema altında gruplandığı sonucuna ulaşılmıştır. Çalışma sonunda çalışmaya katılan özel eğitim öğretmeni adaylarının iş birliğini en çok yapboz parçaları, yapboz, zincir halkaları, bir bitkinin/ ağacın kökleri ve inşaat yapmaya benzettikleri görülmüştür. Özel eğitim öğretmeni adaylarının ürettiği metafor ve gerekçelerinin özel eğitimin yapısı, gereklilikleri, iş birliğinin kalitesini olumsuz etkileyen etmenler ve iş birliğine yönelik tehditler, iş birliğinin önemi ve amaçlarına yönelik olduğu sonucuna ulaşılmıştır. Katılımcılar yapısı ve gereklilikleri bakımından iş birliğinin en çok birden fazla alan uzmanının bir araya geldiği bir yapı olmasına vurgu yapmışlar, tehdit olarak iş birliğinde yer alan uzmanların nitelik ve performanslarının düşük olmasının diğer uzmanların çalışmasını etkilemesi olarak ifade etmişleridir. Katılımcılar özel eğitimde iş birliğinin önemini hizmetlerin etkili ve verimli sağlanması için gerekli olması ile açıklarken, amaçlarını ise genellikle çocuğun ilerletilmesi ile sınırlı tuttukları sonucuna ulaşılmıstır.

Bu çalışmadaki katılımcılar Gazi Üniversitesi Gazi Eğitim Fakültesi Özel Eğitim Öğretmenliği Lisans Programı dördüncü sınıfa devam eden özel eğitim öğretmeni adayları ile sinırlıdır. Bununla birlikte araştırmadan elde edilen sonuçların çalışmaya katılan 93 özel eğitim öğretmeni adayının görüşleri ile sınırlı olduğu göz önünde bulundurulmalıdır. Daha geniş katılımcı gruplarından elde edilecek sonuçlar her zaman daha önemli ve çeşitli bulgular sağlamak için gereklidir. Bu bakımdan ileride yapılacak çalısmalarda daha geniş katılımcı grupları ile çalışılabilir. Katılımcıların iş birliğine yönelik algıları farklı araştırma yöntemleri ile toplanabilir. Bunun yanı sıra araştırmaya katılan özel eğitim öğretmeni adaylarının iş birliğine ilişkin ders almamış olmamaları da metaforik algılarının çeşitliliğinin anlaşılması bakımından ayrı bir sınırlılık olarak görülebilir. Bu durumda iş birliğine yönelik eğitimler alan ve almayan grupların algılarının karşılaştırılması daha derinlemesine bilgiler sağlanması için gerekli olabilir.

\section{Etik Beyan}

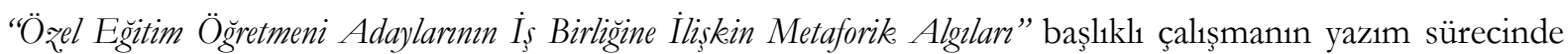
bilimsel kurallara, etik ve alıntı kurallarına uyulmuş; toplanan veriler üzerinde herhangi bir tahrifat yapılmamış ve bu çalışma herhangi başka bir akademik yayın ortamına değerlendirme için gönderilmemiştir. Gerekli olan etik kurul izinleri Gazi Üniversitesi Ölçme Değerlendirme Etik Alt Çalışma Grubu 07.04.2020 tarih ve 04 sayılı toplantısında alınmıştır.

\section{Kaynakça}

Akturan, U. ve Esen, A. (2008). Fenomenoloji. T. Baş ve U. Akturan (Ed.) içinde. Nitel araşstrma yöntemleri (ss. 83-98). Ankara: Seçkin Yayıncilık.

573 No'lu Özel Eğitim Hakkında Kanun Hükmünde Kararname.

http://www.resmigazete.gov.tr/arsiv/23011 1.pdf adresinden 18 Ocak 2019 tarihinde erişilmiştir.

(1997). 
Biggs, E. E., Gilson, C. B. ve Carter, E. W. (2016). Accomplishing more together: Influences to the quality of professional relationships between special educators and paraprofessionals. Research and Practice for Persons with Severe Disabilities, 41(4), 256-272.

Brownell, M. T., Adams, A., Sindelar, P., Waldron, N. ve Vanhover, S. (2006). Learning from collaboration: The role of teacher qualities. Exceptional Children, 72(2), 169-185.

Büyükalan, S. ve Yaylac1, Z. (2018). Normal gelişim gösteren öğrenciler ile kaynaştırma öğrencilerinin sosyal bilgiler kavramına ilişkin metafor algıları. Ozel Egitim Dergisi, 19(4), 679.

Caron, E. A. ve McLaughlin, M. J. (2002). Indicators of beacons of excellence schools: What do they tell us about collaborative practices. Journal of Educational and Psychological Consultation, 13(4), 285-313.

Carter, N., Prater, M. A., Jackson, A. ve Marchant, M. (2009). Educators' perceptions of collaborative planning processes for students with disabilities. Preventing School Failure: Alternative Education for Children and Youth, 54(1), 60-70.

Cerit, Y. (2008). Öğretmen kavramı ile ilgili metaforlara ilişkin öğrenci, öğretmen ve yöneticilerin görüşleri. Türk Ë̆itim Bilimleri Dergisi, 6(4), 693-712.

Cook, L. Ve Friend, M. (1991). Principles for the practice of collaboration in schools. Preventing School Failure: Alternative Education for Children and Youth, 35(4), 6-9.

Cook, L. ve Friend, M. (2010). The state of the art of collaboration on behalf of students with disabilities. Journal of Educational and Psychological Consultation, 20(1), 1-8.

Dayı, E., Açıkgöz, G. ve Elçi, A. N. (2020). Güzel Sanatlar Eğitimi Bölümü öğretmen adaylarının özel gereksinimli öğrencilere yönelik metaforik algıları (Gazi Üniveritesi örneği). Ankara Üniversitesi Eğitim Bilimleri Fakültesi Özel Eğitim Dergisi, 21(1), 95-122.

Ekici, G. (2016). Öğretmen adaylarının"Bilgisayar" kavramına ilişkin metaforik algıları. Gaz̧iantep University Journal of Social Sciences, 15(3), 755-781.

Elçi, A. N. (2019). Öz̧el eğitim okul ve sinflarnnda brans derslerinin yürütülmesinde özel eğitim ve branş ögretmenleri arasindaki is birliği çalısmalarmmn incelenmesi (Yüksek Lisans Tezi). Gazi Üniversitesi Eğitim Bilimleri Enstitüsü, Ankara.

Friend, M. ve Cook, L. (1992). Interactions: Collaboration skills for school professionals. Longman Publishing Group, 95 Church Street, White Plains, NY 10601.

Gürgür, H. ve Uzuner, Y. (2010). Kaynaştırma sınıfında iş birliği ile öğretim uygulamalarına bakışın fenomenolojik analizi. Matrix, 5(2), 15-27.

Hamilton-Jones, B. M. ve Vail, C. O. (2014). Preparing special educators for collaboration in the classroom: Preservice teachers' beliefs and perspectives. International Journal of Special Education, 29(1), 76-86.

Hunt, P., Soto, G., Maier, J. ve Doering, K. (2003). Collaborative teaming to support students at risk and students with severe disabilities in general education classrooms. Exceptional Children, 69(3), 315-332.

İş birliği. (t.y.) http://www.tdk.gov.tr/index.php adresinden 22 Nisan 2019 tarihinde erişilmiştir.

İş birliği. (t.y.) www.wikipedia.org adresinden 22 Nisan 2019 tarihinde erişilmiştir.

Lynch, D., Madden, J. ve Knight, B. A. (2014). Harnessing professional dialogue, collaboration and content in context: An exploration of a new model for teacher professional learning. International Journal of Innovation, Creativity and Change, 1(3), 1-15.

Mandel, C. J. ve Fiscus, E. D. (2002). Bireyselleştirilmiş ĕğtim programlarmmn geliş̧tirilmesi BEP (2. Baskı) (G. Akçemete Ed. Çeviri, H. G Şenel, E. Tekin). Ankara. Kişisel Yayın Evi.

Martinez, M. A., Saudela, N. ve Huber, G.L. (2001). Metaphors as blueprints of thinking about teaching and learning. Teaching and Teacher Education, 17, 965-977.

Merriam, S. B. (2013). Nitel araştırma. Desen ve uygulama için bir rehber. (Çev. Editörü: Selahattin Turan, Çev. Dinç, E.) içinde (ss. 199-228). Ankara: Nobel Akademik Yayıncılik.

Miles, M. B. ve Huberman, A.M. (1994). Qualitative data analysis. Thousand Oaks, CA: Sage.

Tamimi, Y. (2005). Örgüt külttürünün metaforlarla analį̨i. (Yüksek Lisans Tezi). Osmangazi Üniversitesi. Eskişehir.

Thousand, J. S., Villa, R. A. ve Nevin, A. I. (2006). The many faces of collaborative planning and teaching. Theory into Practice, 45(3), 239-248.

Vuran, S., Bozkuş-Genç, G. ve Sani-Bozkurt, S. (2017). İş birliği ile bireyselleştirilmiş eğitim programı geliştirme süreci: Durum çalışmas1. Ankara Üniversitesi Eğitim Bilimleri Fakültesi Öz̧el Eğitim Dergisi, 18(2), 165-184.

Winn, J. ve Blanton, L. (2005). The call for collaboration in teacher education. Focus on Exceptional Children, 38(2), 112.

Yazar, T., Özekinci, B. ve Lala, Ö. (2017). Öğretmen ve okul yöneticilerinin değerler eğitimi kavramına ilişkin metaforik alg1lar1. Eğitimde Nitel Arastırmalar Dergisi - Journal of Qualitative Research in Education, 5(3), 245-269.

Yener, C. (2019). Kaynaştırma ögrencileri ile çalıs̆ma yapan uz̧manlar arasindaki BEP sürecindeki is birliğinin uæman ve aile görüslerine dayalı olarak belirlenmesi. (Yüksek Lisans Tezi). Gazi Üniversitesi Eğitim Bilimleri Enstitüsü.

Zagona, A. L., Kurth, J. A. ve MacFarland, S. Z. (2017). Teachers' views of their preparation for inclusive education and collaboration. Teacher Education and Special Education, 40(3), 163-178. 


\section{EXTENDED ABSTRACT}

Collaboration is a concept that special education teachers and preservice special education teachers develop as a result of certain training and experiences with the help of their own skills and abilities (Biggs et al., 2016; Brownell et al., 2006, p. 169). In addition, when teachers and other field experts have similar perspectives (Gürgür, \& Uzuner, 2010, p. 15) and are able to discuss their opinions openly, this affects the attitudes of teachers towards collaboration (Lynch et al., 2014, p. 1). Furthermore, studies have indicated that when preservice teachers are provided with the appropriate training, their knowledge and skill levels on collaboration would increase (Biggs et al., 2016; Brownell et al., 2006, p. 169; Hamilton et al., 2013, p. 76; Vuran et al., 2017; Zagona et al., 2017, p. 163). This study examined the perception of pre-service special education teachers in relation to collaboration. The basic perceptions of the preservice special education teachers who participated in the study constituted a matter of curiosity due to the fact that they had not received training on collaboration in special education and they were in their senior years. Collaboration is defined as a concept that has many features and unique principles, and cannot be explained easily (Cook \& Friend, 1991, p. 6; Cook \& Friend, 2010, p. 1; Friend \& Cook, 1992). Therefore, in terms of understanding their perspectives, it may be useful for the preservice special education teachers to explain their perceptions of collaboration with the help of metaphors. Considering the fact that the preservice teachers who participated in the study were in their senior years and would start their profession soon, the results that could be obtained as a result of determining their perceptions of collaboration are believed to be useful in terms of developing suggestions for preservice and in-service training programs on this subject. In addition, it is believed that the results obtained from the study would provide qualified data to the literature.

The purpose of this study is to analyze the metaphors developed by preservice special education teachers regarding the concept of "collaboration". In this context, answers to the following questions were sought:

1. What are the metaphors of preservice special education teachers regarding the concept of "collaboration"?

2. What are the themes that the identified metaphors could be collected in terms of their common characteristics?

The research pattern is a model of phenomenology, which is one of the qualitative research models. Phenomenology pattern is used to reveal common practices and to define and explain the meanings/facts created by the participants (Akturan, \& Esen, 2008, p. 83-98). The "Metaphoric Perception Survey" was created by the researchers, which was similar to the studies conducted in the literature (Büyükalan, \& Yaylac1, 2018, p. 679; Day1, Açıkgöz, \& Elçi, 2020, p. 95; Ekici, 2016, p. 755; Yazar et al., 2017, p. 245). In the survey, there was a semi-structured question in the form of "Collaboration in special education is like ; because. ..." The data of the study were collected from the senior year students enrolled at the special education department of Gazi University, Gazi Education Faculty. The study enrolled 107 participants and used a metaphorical perception survey.

The data collection process began after obtaining the necessary ethical approvals. In order to collect the data, the researchers received preliminary information about the curriculum from the academic advisors of the participating preservice teachers. Announcements were made to reach the maximum number of participants at once and it was ensured that all participants were together at the same time. The first and second researchers collected the data of the study by administering the "Metaphoric Perception Survey" to the participants at the specified time. During the data collection phase, data were collected from 107 participants, and 14 surveys were excluded from the analysis because they did not receive proper responses. Data from the remaining 93 surveys were analyzed by using content analysis.

It was concluded that the participants created 56 different metaphors. The concepts that were most frequently associated with the concept of collaboration in special education were the chain link $(f=6)$ and puzzle piece $(f=5)$. The other three most common metaphors created by the preservice special education teachers were observed to be puzzle $(f=4)$, roots of a tree/plant $(f=3)$, and building/construction $(f=3)$. The frequency was found to be 2 for the 16 metaphors created by the participants (building/construction, chain, tree, family, key and lock, building, gears, wall, foundation of the house/building, football team, blood, organs, spider web, fingers, clock, train/train wagon, body). The frequency was found to be 1 for the last 24 metaphors produced by the participants (mother, beehive, honeycomb, climbing a mountain, 
rare Indian fabric, flowering, domino stones, knot, bridge, dry beans and rice, birds nest, flying bird, parts of a machine, mechanism, stair steps, mutual relationship, struggle, knitting, sugar, company, seesaw, wheel, iskender kebab with butter, salt). According to the results of the study, it was seen that the metaphors of the participants could be collected under 5 different themes. In order of frequency these themes were as follows: in terms of the structure of the collaboration ( $\mathrm{f}=33,35.48 \%)$, in terms of the threats to collaboration and factors that affect its success negatively ( $\mathrm{f}=20,21.5 \%$ ), in terms of the importance of collaboration $(\mathrm{f}=19,20.43 \%)$, in terms of the requirements of collaboration $(\mathrm{f}=15$, $16.12 \%)$, and in terms of the purpose of collaboration $(\mathrm{f}=6,6.45 \%)$.

According to the definitions and explanations regarding the characteristics of collaboration, collaboration is perceived as a process in which multiple cooperators gather for a common purpose, share resources, and knowledge together and equally to achieve their purpose and undertake the responsibilities of the decisions and consequences together (Cook, \& Friend, 1991, p. 6; Cook, \& Friend, 2010; Friend, \& Cook, 1992). The concept of collaboration is observed to be an interactive approach, in which multiple cooperators gather to work on a voluntary basis and take decisions for a purpose. In addition, in order collaboration to be ensured and sustained, stakeholders should take common responsibilities to work and make decisions on the equal, voluntary and participative basis (Cook, \& Friend, 1991, p. 6; Cook, \& Friend, 2010; Friend, \& Cook, 1992), and possess the skills of interaction with multiple people, effective problem solving and taking responsibilities (Thousand et al. 2006; Winn \& Blanton, 2005). It was seen that the results obtained from the study and the results of the studies in the literature on collaboration had similar structures.

In the study, it was observed that the preservice special education teachers associated collaboration most frequently with puzzle pieces, puzzles, chain links, roots of a plant/ tree, and construction. It was concluded that the metaphors created by preservice special education teachers and their reasons were related to the structure and requirements of collaboration, factors affecting its quality, threats to collaboration, the importance and the purpose of collaboration. Participants highlighted the structure in which several field experts come together; and in terms of threats, they expressed the influence of lowperforming and unqualified experts on the work of other experts during the collaboration. Participants described the importance of collaboration in special education by mentioning its necessary to ensure effective and productive services and their expressions about the purpose of the collaboration was generally limited to the improvement of the child. 